\title{
Synthesis of $( \pm)$-mevalonic acid lactone via a meso-dialdehyde: a model for desymmetrization
}

\author{
Shirley L. J. Buckley, Laurence M. Harwood*, and Antonio J. Macías-Sánchez \\ Department of Chemistry, University of Reading, Whiteknights, Reading, Berkshire RG6 6AD, \\ $U K$ \\ E-mail: l.m.harwood@reading.ac.uk
}

\begin{abstract}
Dedicated to Professor A. Padwa on the occasion of his $65^{\text {th }}$ birthday
(received 08 May 02; accepted 29 Jul 02; published on the web 06 Aug 02)
\end{abstract}

\begin{abstract}
Two procedures are described for the preparation of the racemic mevalonic lactone $( \pm)-2$, via a meso-dialdehyde $\mathbf{8}$. The preparation of compound $\mathbf{8}$ in seven steps from cyclopentadiene is also described. This procedure intends to be model for a desymmetrization study of dialdehyde $\mathbf{8}$, leading to optically active $(-)(R)$ - and $(+)(S)$ - mevalonolactone, 2.
\end{abstract}

Keywords: Desymmetrization, model, mevalonic acid lactone

\section{Introduction}

Mevalonic acid, which exists in an equilibrium between its open $(-)-(R)-\mathbf{1}$ and cyclic form (mevalonolactone, $(-)-(R)-2)$, is a key intermediate in cellular biochemistry. ${ }^{1}$ It is a precursor for a number of biologically important lipids, including cholesterol, steroid hormones, bile acids, ubiquinone and dolichols. In addition, mevalonate-derived isoprenoids are intermediates in the biosynthesis of isoprenylated tRNAs, prenylated proteins involved in cell signaling and growth, and heme a, a prosthetic group of cytochrome oxidase. It is also the biogenetic precursor of most terpenoids, steroids, carotenoids and isoprenoids ${ }^{2}$ and has therefore been a synthetic target of considerable interest.

Mevalonolactone (-)-(R)-2 was first discovered and synthesized via resolution by Folkers and co-workers. ${ }^{3}$ Since then a number of asymmetric syntheses of this molecule have been published, the most popular of which involves the Sharpless epoxidation of a suitable allylic alcohol. ${ }^{4}$ The chiral pool materials such as linalool, ${ }^{5}$ quinic acid, ${ }^{6}$ 2-methyl-2-hydroxy- $\gamma$ butyrolactone, ${ }^{7}$ a chiral equivalent of cyclohexa-2,5-dienone, ${ }^{8}$ and the chiral template $1,2: 5,6$-diO-isopropylidene- $\alpha$-D-glucofuran-3-ulose ${ }^{9}$ were reported as sources for the preparation of mevalonolactone. Other interesting synthetic methodologies involve the use of chiral 
sulfoxides, ${ }^{10}$ 1,3-oxathianes, ${ }^{11}$ and axially dissymmetric binaphthyldiamines. ${ }^{12}$ In addition, several enzymatic syntheses starting from achiral precursors have been described in the literature. ${ }^{13}$ However, many of these methods suffer either from poor enantiomeric purity or low chemical yield, ${ }^{10,12}$ and therefore there is room for new approaches.

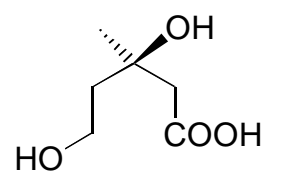

$(-)(R)-1$

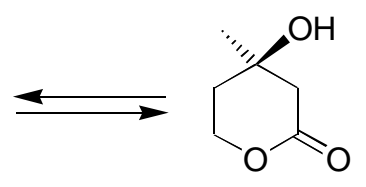

(-) (R)- 2

\section{Scheme 1}

Desymmetrization is proving to be a powerful synthetic tool, ${ }^{14}$ and dialdehydes have been the focus of a number of studies. ${ }^{15}$ With this methodology, instead of incorporating the chirality from the very beginning of the synthesis, a certain level of elaboration can be incorporated into the meso- molecule prior to the enantioselective desymmetrization step. We present here a model study of the synthesis of racemic mevalonic acid lactone $( \pm)-2$, which can be applied to a enantioselective synthesis of $(-)-(R)-$ and $(+)-(S)-$ mevalonolactone, 2 , as we have shown recently in the synthesis of $(+)-(S)-$ and $(-)-(R)$ - nor-methyl mevaldate derivatives. ${ }^{16}$

\section{Results and Discussion}

Although several approaches to analogues of the dialdehyde 8 have been reported, ${ }^{17}$ we found it to be conveniently prepared through a seven-step sequence from cyclopentadiene. The alcohol 5 was obtained from cyclopentadiene via epoxide 3, following the procedure of Crandall. ${ }^{18}$ Rearrangement of $\mathbf{3}$ to cyclopent-3-enone, 4 , catalyzed by $\mathrm{Pd}\left(\mathrm{Ph}_{3}\right)_{4},{ }^{19}$ and treatment with $\mathrm{MeMgCl}$ led to the alcohol $\mathbf{5}$ in $18 \%$ overall yield. The alcohol $\mathbf{5}$ was protected as its $t-$ butyldimethylsilyl ether 6 in $95 \%$ yield (TBDMSOTf-DIPEA, $\mathrm{CH}_{2} \mathrm{Cl}_{2},-78^{\circ} \mathrm{C}$ ), identified by the disappearance of the hydroxyl absorption in the infrared spectrum and the replacement of the apparent singlet in the ${ }^{1} \mathrm{H}-\mathrm{NMR}$, corresponding to the methylene groups of the unprotected alcohol 5 at $\delta 2.44 \mathrm{ppm}$, with two $2 \mathrm{H}$ doublets $(\delta 2.43$ and $\delta 2.25, \mathrm{~J} 15 \mathrm{~Hz})$ in $\mathbf{6}$. The protected alcohol 6 was transformed into a 5:1 mixture of diastereoisomeric diols 7 by the method of Matteson, employing catalytic osmium tetroxide in t-butanol at reflux with trimethylamine- $N$ oxide as the reoxidant. ${ }^{20}$ Cleavage of 7 with sodium periodate in 8:2 dioxane-water, followed by exhaustive extraction with ethyl acetate furnished diol $\mathbf{8}$, which forms the cyclic hydrate $\mathbf{9}$ on standing. It is possible to transform the hydrate back to the dialdehyde by treating with powdered $4 \AA \AA$ molecular sieves in refluxing THF for 2 hours.

Once the meso-dialdehyde 8 was obtained, we aimed at a preparation of mevalonic lactone $( \pm)-2$ which would be used for enantioselective differentiation of the aldehyde groups in 
compound 8. In order to do this, two different approaches to the mevalonic lactone were examined. In the first, a direct reduction of either of the prochiral aldehyde groups, followed by attack on the remaining carbonyl would lead to a ring closure. A final oxidation of the resulting alcohol, and deprotection of the silyl group would complete the synthesis of the racemic lactone $( \pm)-2$.

Treatment of the dialdehyde 8 with 1.5 equivalents of $\mathrm{NaBH}_{4}$ in dry methanol at $-30^{\circ} \mathrm{C}$ afforded the lactol 10. As a model, 2-hydroxytetrahydropyran, 11, was prepared as reported by Schniepp et al. in 40\% yield (Scheme 3). ${ }^{21}$ The ${ }^{1} \mathrm{H}-\mathrm{NMR}$ spectra of lactols $\mathbf{1 0}$ and $\mathbf{1 1}$ were then compared, to support the production of the lactol 10. In the ${ }^{1} \mathrm{H}-\mathrm{NMR}$ spectrum of 2hydroxytetrahydropyran, 11, a broad singlet at $\delta 4.90 \mathrm{ppm}$ corresponding to the anomeric proton was matched by a broad singlet at $\delta 4.98 \mathrm{ppm}$ in the spectrum of lactol $\mathbf{1 0}$. The protons of the methylene group adjacent to the lactol oxygen are diastereotopic, appearing as two separate multiplets at $\delta .4 .03-4.00$ and $\delta .3 .55-3.47$ in the hydroxytetrahydropyran 11 spectrum and at $\oint 3.72-3.65$ and $\delta 3.55-3.42$ in the lactol 10 spectrum.
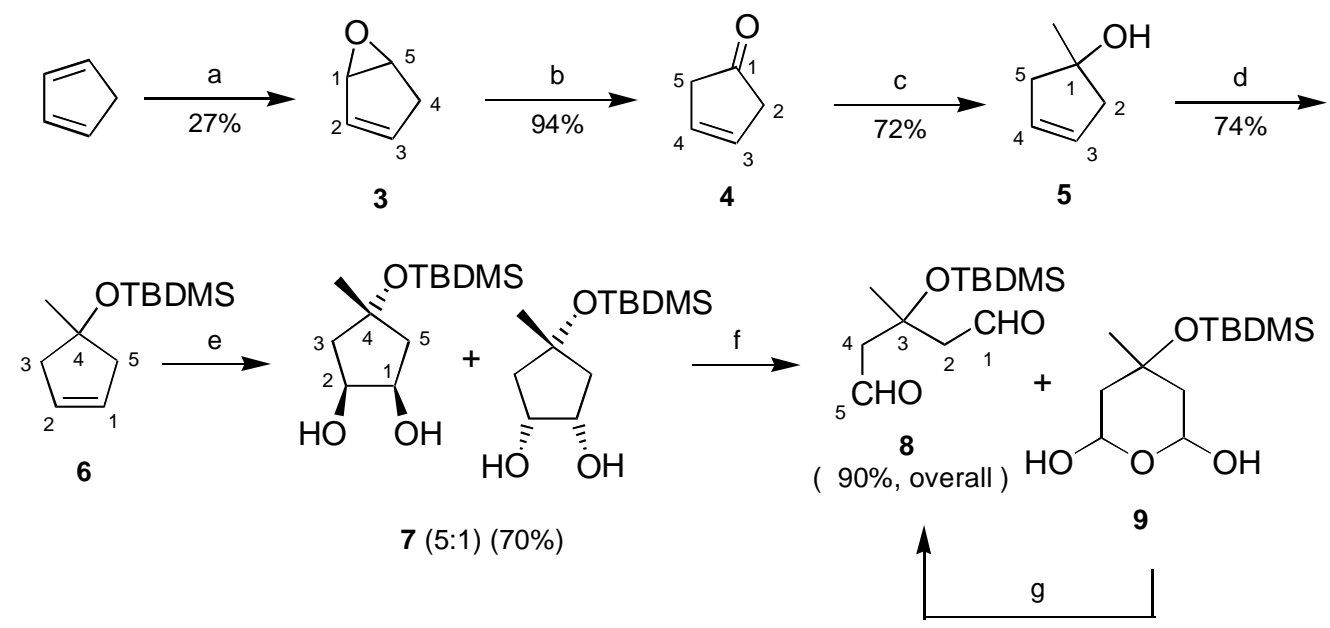

Scheme 2. (a) $\mathrm{CH}_{3} \mathrm{CO}_{3} \mathrm{H}, \mathrm{CH}_{3} \mathrm{CO}_{2} \mathrm{Na}, \mathrm{Na}_{2} \mathrm{CO}_{3}, \mathrm{CH}_{2} \mathrm{Cl}_{2}, \mathrm{~T}<10^{\circ} \mathrm{C}$; (b) $\mathrm{Pd}\left(\mathrm{Ph}_{3}\right)_{4}, \mathrm{CH}_{2} \mathrm{Cl}_{2}$, r.t.; (c) $\mathrm{MeMgBr}$; (d) TBDMSOTf, DIPEA, THF, $-78^{\circ} \mathrm{C}$; $\mathrm{OsO}_{4},\left(\mathrm{CH}_{3}\right)_{3} \mathrm{NO}$, pyr, t-BuOH, $\mathrm{H}_{2} \mathrm{O}$, reflux; $\mathrm{NaIO}_{4}$, dioxane/ $\mathrm{H}_{2} \mathrm{O},(8: 2)$, r.t.; (g) $4 \AA$ mol. sieves, THF, reflux.

The remaining methylene groups were observed in the $\$ 1.00-2.00$ region. The presence of lactol 10 was further indicated by the observation of a molecular ion of $\mathrm{m} / \mathrm{z} 229$ corresponding to the loss of water in the mass spectrum. The crude lactol $\mathbf{1 0}$ was subsequently oxidized with a suspension of PCC and $4 \AA$ molecular sieves at room temperature over 24 hours to furnish the lactone 12, in 43\% yield over 2 steps, after chromatographic purification (Scheme 3). The lactone was characterized by two distinctive multiplets at $\delta 4.51-4.41$ and $\delta 4.26-4.18$, corresponding to the diastereotopic protons of the methylene group adjacent to the lactone oxygen, in the ${ }^{1} \mathrm{H}-\mathrm{NMR}$ spectrum, and the strong lactone carbonyl absorption at $1743 \mathrm{~cm}^{-1}$ in the 
infrared spectrum. Finally, treatment of the protected lactone 12 with $\mathrm{HCl}(10 \%$, aqueous) in THF for $48 \mathrm{~h}$ afforded racemic mevalonic lactone $( \pm)-2$ in $29 \%$ yield.

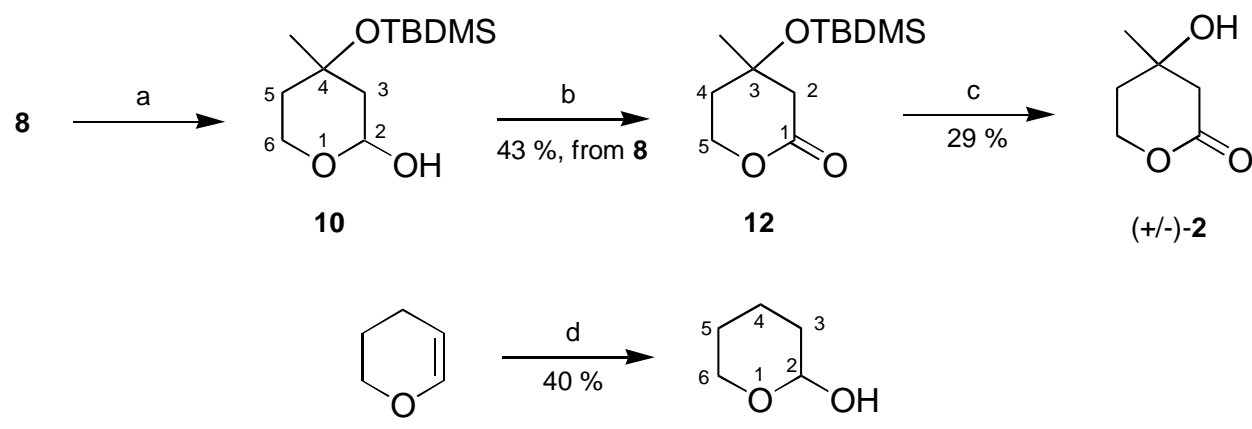

11

Scheme 3. (a) $\mathrm{NaBH}_{4}, \mathrm{MeOH},-30^{\circ} \mathrm{C}$; (b) PCC, $4 \AA$ mol. sieves, $\mathrm{CH}_{2} \mathrm{Cl}_{2}$, r.t. (c) $\mathrm{HCl}(10 \%$, aqueous), THF, r.t.; (d) $\mathrm{HCl}(2 M), \Delta$.

The second alternative approach would aim to differentiate between the two prochiral aldehyde groups, by using an appropriate alcohol which would act as a chiral auxiliary in the stereo-differentiating process. Treatment of the adduct with an alkoxide would open the lactone, with the recovery of the chiral auxiliary. Reduction of the aldehyde, re-lactonization, and deprotection of the silyl group would yield the mevalonic acid lactone $( \pm)-2$. This approach has been put in practice in the synthesis, recently described by our group, of $(+)-(S)-$ and $(-)-(R)-$ nor-methyl mevaldate derivatives. ${ }^{16}$ To this end, the dialdehyde 8 was treated with 1 equiv. of $\mathrm{EtOH}$ in THF and heated at reflux for $24 \mathrm{~h}$. The crude reaction material obtained from this reaction was immediately oxidized with a suspension of PCC and $4 \AA$ molecular sieves at room temperature over $24 \mathrm{~h}$, to furnish 14 in $44 \%$ yield over 2 steps, after chromatographic purification. Treatment of the compound 14 with sodium ethoxide in $\mathrm{Et}_{2} \mathrm{O}$ at $0^{\circ} \mathrm{C}$ yielded 15, which possesses a resonance in its ${ }^{1} \mathrm{H}-\mathrm{NMR}$ spectrum at $\delta 9.75(\mathrm{t}, 1 \mathrm{H}, \mathrm{J} 2.6 \mathrm{~Hz})$, characteristic of an aldehyde adjacent to a methylene group. The next stage involved ring closure to provide the protected lactone 12. Even though a two-step procedure was expected to be required, treatment of 15 with 2 equivalents of $\mathrm{NaBH}_{4}$ in $\mathrm{EtOH}$ at $-30^{\circ} \mathrm{C}$, afforded directly the protected racemic lactone 12 in 44\% yield. Finally, racemic mevalonolactone ( \pm )-2 was obtained from 12 by the procedure described previously. 


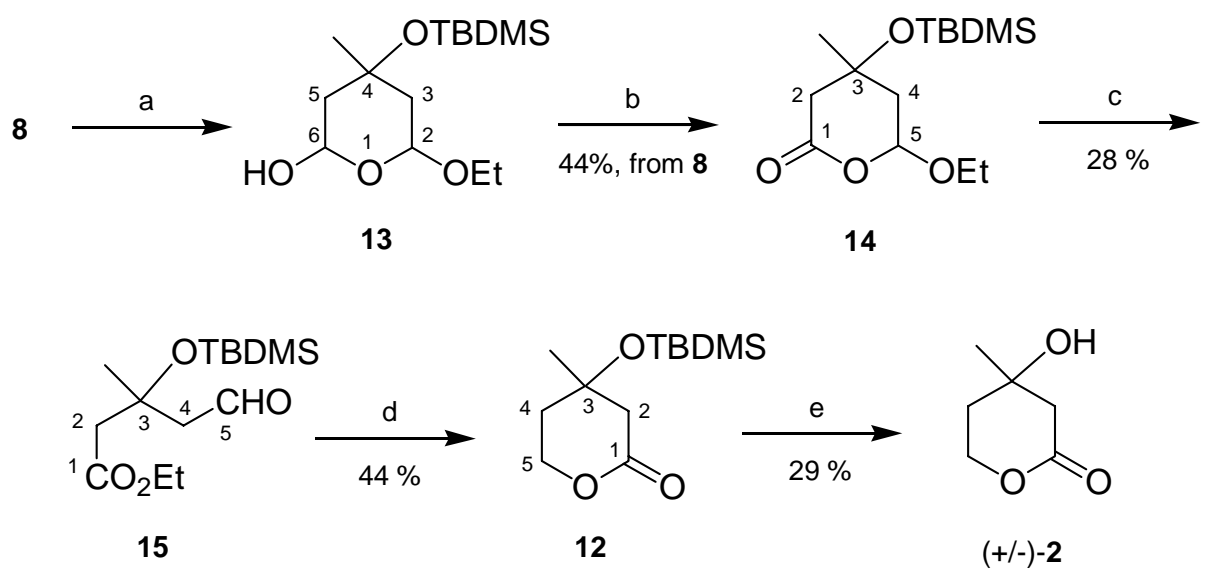

Scheme 4. (a) Ethanol, THF, reflux, 24 h; (b) PCC, $4 \AA$ mol. sieves, $\mathrm{CH}_{2} \mathrm{Cl}_{2}$, r.t.; (c) EtONa, $\mathrm{Et}_{2} \mathrm{O}, 0^{\circ} \mathrm{C}$; (d) $\mathrm{NaBH}_{4}, \mathrm{MeOH},-30^{\circ} \mathrm{C}$; (e) $\mathrm{HCl}(2 \mathrm{M}), \tilde{\Delta}$

In conclusion, two procedures have been described for the preparation of the racemic mevalonic lactone $( \pm)$-2, vía a meso-dialdehyde $\mathbf{8}$. The preparation of compound $\mathbf{8}$, in seven steps, from cyclopentadiene is also described. This procedure is intended to be model for a desymmetrization study of dialdehyde 8, leading to optically active $(-)-(R)$ and $(+)-(S)$ mevalonolactone, 2 .

\section{Experimental Section}

General Procedures. Spectroscopic data were recorded with the following instruments: Perkin Elmer Paragon FT-IR or Perkin Elmer 1720-X spectrophotometers (IR); Bruker WM 250, Bruker DPX250 (NMR: ${ }^{1} \mathrm{H}$ at $250 \mathrm{MHz},{ }^{13} \mathrm{C}$ at $62.5 \mathrm{MHz}$ ) and Jeol EX 400 (NMR: ${ }^{1} \mathrm{H}$ at 400 $\mathrm{MHz},{ }^{13} \mathrm{C}$ at $100 \mathrm{MHz}$ ). The assignment of ${ }^{1} \mathrm{H}$ and ${ }^{13} \mathrm{C}$ NMR signals is based on two-dimensional NMR techniques. Signal positions are recorded in $\delta$, with the abbreviations s, d, t, q, dd, ddd, dt, $\mathrm{dq}, \mathrm{br}$, and $\mathrm{m}$, representing singlet, doublet, triplet, quartet, double doublet, double double doublet, double triplet, double quartet, broad and multiplet, respectively. Mass spectra $(\mathrm{m} / \mathrm{z})$ and accurate mass data (HRMS) were recorded on a Fisons VG Autospec mass spectrometer. Spectra were obtained using chemical ionization or electron impact methods as stated. Microanalyses were carried out by Medac Ltd. at Brunel University (UK). Melting points (m.p.) were determined with a Kofler hot stage microscope (Reichert) and are uncorrected. Flash column chromatography was performed according to the method by Still et al. with Silica gel 60 (Merck 9385) using a head pressure by means of head bellows. ${ }^{22}$ T.L.C. analyses were carried out using $0.25 \mathrm{~mm}$ silica gel precoated aluminum- or glass- backed plates with fluorescent indicator, $\mathrm{UV}_{254}$. Spots were visualized by quenching of UV fluorescence, by staining with a potassium permanganate solution, by staining with a vanillin solution, or by staining with a molybdate solution. Reagents and solvents obtained from Aldrich, Avocado, BDH, Fisher, Fluka, and 
Lancaster chemical suppliers were used directly as supplied or following purification according to procedures described by Perrin and Armarego. ${ }^{23}$ Diethyl ether and tetrahydrofuran were distilled over sodium-benzophenone ketyl radical, and dichloromethane was distilled by refluxing over calcium hydride. Methanol and ethanol were distilled from calcium chloride and stored over $4 \AA$ molecular sieves. Diisopropylethylamine was distilled and stored over potassium hydroxide pellets. Light petroleum refers to the fraction in the boiling point range of $30-40^{\circ} \mathrm{C}$, which was fractionally distilled through a Vigreux column prior to use.

6-Oxa[3.1.0]bicyclohex-2-ene (3). ${ }^{18}$ Freshly distilled cyclopentadiene $(160.42 \mathrm{~g}, 2.43 \mathrm{~mol})$ was added to mechanically stirred $\mathrm{Na}_{2} \mathrm{CO}_{3}(308.70 \mathrm{~g}, 2.91 \mathrm{~mol})$ in $\mathrm{CH}_{2} \mathrm{Cl}_{2}(1.15 \mathrm{~L})$ at $0^{\circ} \mathrm{C}$. Peracetic acid $(335 \mathrm{~mL}, 1.94 \mathrm{~mol})$ pre-treated with sodium acetate $(5.97 \mathrm{~g}, 0.073 \mathrm{~mol})$ was slowly added to the reaction mixture. The temperature of the reaction was kept below $20^{\circ} \mathrm{C}$ throughout the addition. After $2 \mathrm{~h}$ the inorganic solids were removed by filtration and washed thoroughly with $\mathrm{CH}_{2} \mathrm{Cl}_{2}(1.5 \mathrm{~L})$. The $\mathrm{CH}_{2} \mathrm{Cl}_{2}$ was removed by distillation at $760 \mathrm{mmHg}$ to give the crude epoxide. Purification was achieved via distillation to give pure epoxide $\mathbf{3}$ as a pale yellow oil (52.93 g, 27 \%), b.p. $36-38^{\circ} \mathrm{C} / 45 \mathrm{~mm} \mathrm{Hg}$; lit. $^{18} 39-41^{\circ} \mathrm{C} / 146 \mathrm{~mm} \mathrm{Hg}$ ); IR (film) $v_{\max }, 3049$, 2910, 1674 and $1283 \mathrm{~cm}^{-1}$; ${ }^{1} \mathrm{H}-\mathrm{NMR}\left(400 \mathrm{MHz}, \mathrm{CDCl}_{3}\right): \delta_{\mathrm{H}} 6.17-6.13(\mathrm{~m}, 1 \mathrm{H}, \mathrm{H}-2), 6.01-5.96$

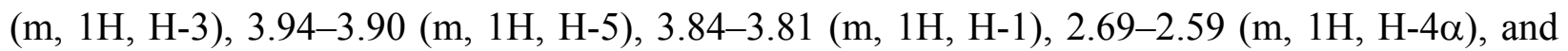
2.44-2.34 (114, m, H-43); ${ }^{13} \mathrm{C}-\mathrm{NMR}\left(250 \mathrm{MHz}, \mathrm{CDCl}_{3}\right) \delta_{\mathrm{C}} 138.2,131.6,59.5,57.2$, and 36.0; EIMS m/z (\%): $82\left(100 \%, \mathrm{M}^{+}\right) ; \mathrm{C}_{5} \mathrm{H}_{6} \mathrm{O}$ requires 82.0419 , found 82.0425 .

Cyclopent-3-enone (4). ${ }^{19} \mathrm{~A}$ catalytic amount of tetrakis(triphenylphosphine)palladium was added to a solution of epoxide $3(11.21 \mathrm{~g}, 0.14 \mathrm{~mol})$ in $\mathrm{CH}_{2} \mathrm{Cl}_{2}(75 \mathrm{~mL})$ at $0^{\circ} \mathrm{C}$. The reaction was stirred for $21 \mathrm{~h}$ at room temperature. Most of the solvent was removed in vacuo and the residue then filtered through a pad of Celite ${ }^{\circledR}$, washed through with diethyl ether $(200 \mathrm{~mL})$. Most of the ether was removed in vacuo and the remainder was removed under a stream of nitrogen to give pure ketone 4 as a yellow oil (10.56 g, $94 \%$ ); IR (film) $v_{\max }: 2972,2901,1748$ and $1611 \mathrm{~cm}^{-1}$; ${ }^{1} \mathrm{H}-\mathrm{NMR}\left(400 \mathrm{MHz}, \mathrm{CDCl}_{3}\right): \delta_{\mathrm{H}} 6.09$ (br. s, $2 \mathrm{H}, \mathrm{H}-3$ and H-4), and $2.88(4 \mathrm{H}$, br. s, H-2 and H5); ${ }^{13} \mathrm{C}-\mathrm{NMR}\left(250 \mathrm{MHz}, \mathrm{CDCl}_{3}\right): \delta_{\mathrm{C}} 217.6,129.0$, and 43.0; EIMS m/z (\%): $82\left(41 \%, \mathrm{M}^{+}\right)$; $\mathrm{C}_{5} \mathrm{H}_{6} \mathrm{O}$ requires 82.0419, found 82.0426.

1-Methylcyclopent-3-enol (5). ${ }^{23}$ Methyl magnesium chloride $(27.2 \mathrm{~mL}$ of $3 \mathrm{M}$ solution), $81.72 \mathrm{mmol})$ was added to a solution of ketone $4(6.70 \mathrm{~g}, 81.72 \mathrm{mmol})$ in diethyl ether $(100 \mathrm{~mL})$ at $0{ }^{\circ} \mathrm{C}$. The reaction was stirred at $0^{\circ} \mathrm{C}$ for $30 \mathrm{~min}$. then quenched with saturated $\mathrm{NH}_{4} \mathrm{Cl}$ $(20 \mathrm{~mL})$. The layers were separated and the aqueous layer was extracted with ether $(4 \times 50 \mathrm{~mL})$. The combined organic layers were washed with brine $(2 \times 30 \mathrm{~mL})$, water $(1 \times 30 \mathrm{~mL})$, dried over $\mathrm{MgSO}_{4}$, and concentrated in vacuo to give pure alcohol 5 as a colorless oil (5.756 g, $72 \%$ ); IR (film) $v_{\max }: 3370,2967,2927$, and $1616 \mathrm{~cm}^{-1} ;{ }^{1} \mathrm{H}-\mathrm{NMR}\left(400 \mathrm{MHz}, \mathrm{CDC}_{3}\right.$ ): $\delta_{\mathrm{H}} 5.67$ (br s, $2 \mathrm{H}$, $\mathrm{H}-3$ and H-4), 2.44 (br s, 4H, H-2 and H-5), and 1.43 (s, 3H, $\mathrm{CH}_{3}$ ); ${ }^{13} \mathrm{C}-\mathrm{NMR}(250 \mathrm{MHz}$, $\left.\mathrm{CDCl}_{3}\right): \delta_{\mathrm{C}} 129.1,79.4,48.9$, and 28.4; EIMS m/z (\%): $98\left(23 \%, \mathrm{M}^{+}\right) ; \mathrm{C}_{6} \mathrm{H}_{10} \mathrm{O}$ requires 98.0731, found 98.0739 . 
4-Methyl-4-tert-butyldimethylsilyloxycyclopentene (6). $N, N$-Diisopropylethylamine (7.32 mL, $41.85 \mathrm{mmol})$ was added to alcohol $5(3.42 \mathrm{~g}, 34.88 \mathrm{mmol})$ in $\mathrm{CH}_{2} \mathrm{Cl}_{2}(30 \mathrm{~mL})$ at $-78^{\circ} \mathrm{C}$, followed by tert-butyldimethylsilyl trifluoromethanesulfonate $(8.78 \mathrm{~mL}, 38.37 \mathrm{mmol})$. The reaction was stirred at $-78^{\circ} \mathrm{C}$ for $2.5 \mathrm{~h}$, and then warmed to room temperature. $\mathrm{CH}_{2} \mathrm{Cl}_{2}(50 \mathrm{~mL})$ was added, and the mixture was washed with water $(3 \mathrm{x} 30 \mathrm{~mL})$. The combined organic layers were dried over $\mathrm{MgSO}_{4}$ and concentrated in vacuo to give the pure silyl ether 6 as a colorless oil (5.54 g, $74 \%$ ) IR (film) $v_{\max }: 2957,2930$, and $1473 \mathrm{~cm}^{-1} ;{ }^{1} \mathrm{H}-\mathrm{NMR}\left(400 \mathrm{MHz}, \mathrm{CDC1}_{3}\right): \delta_{\mathrm{H}} 5.59$ (s, 2H,

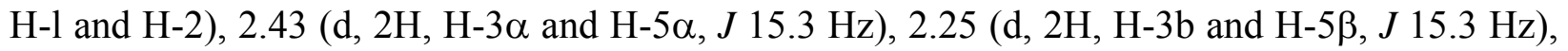
$1.35\left(\mathrm{~s}, 3 \mathrm{H}, \mathrm{CH}_{3}\right), 0.84\left(\mathrm{~s}, 9 \mathrm{H},\left(\mathrm{CH}_{3}\right)_{3} \mathrm{C}\right)$, and $0.05\left(\mathrm{~s}, 6 \mathrm{H},\left(\mathrm{CH}_{3}\right)_{2} \mathrm{Si}\right) ;{ }^{13} \mathrm{C}-\mathrm{NMR}(250 \mathrm{MHz}$, $\left.\mathrm{CDCl}_{3}\right): \delta_{\mathrm{C}} 128.9,81.3,49.0,30.1,25.8,18.2,-2.6$, and -2.9 .

4-Methyl-4-[tert-butyldimethylsilyloxy]cyclopentane-1,2-diol (7). tert-Butanol (2.0 mL), trimethylamine- $N$-oxide $(0.15 \mathrm{~g} 1.361 \mathrm{mmol})$, pyridine $(80 \mu \mathrm{L}, 0.99 \mathrm{mmol})$ and water $(1.6 \mathrm{~mL})$ were added to silyl ether $6(1 \mathrm{mmol})$ at room temperature. Osmium tetroxide (40 $\mu \mathrm{L}, 2.5$ wt. \% solution in $\mathrm{t}-\mathrm{BuOH}, 0.003 \mathrm{mmol}$ ) was then added and the reaction heated to reflux for $20 \mathrm{~h}$. The reaction was then cooled to room temperature, sodium bisulfite $(20 \mathrm{~mL}, 20 \% \mathrm{w} / \mathrm{v})$ was added and the reaction mixture was stirred for a further $1 \mathrm{~h}$. Most of the butanol and water was removed in vacuo, and the residue was then extracted into diethyl ether $(3 \mathrm{x} 30 \mathrm{~mL})$. The combined organic layers were washed wíth brine $(1 \times 30 \mathrm{~mL})$, dried over $\mathrm{MgSO}_{4}$ and concentrated in vacuo to give the pure diol 7. Colorless solid (4.58 g, $70 \%)$, as a mixture of two isomers in a ratio of 5:1, m.p. $58-60^{\circ} \mathrm{C}$; (Found $\mathrm{C}, 58.5, \mathrm{H}, 10.85 \% ; \mathrm{C}_{12} \mathrm{H}_{26} \mathrm{O}_{3} \mathrm{Si}$ requires C, 58.5, $\mathrm{H}, 10.65 \%$ ); IR (film) $v_{\max }: 3341,3234,2956$, and $2934 \mathrm{~cm}^{-1} ;{ }^{1} \mathrm{H}-\mathrm{NMR}\left(400 \mathrm{MHz}, \mathrm{CDC} 1_{3}\right): \delta_{\mathrm{H}}$ 4.23-4.19 (major isomer, $\mathrm{m}, 2 \mathrm{H}, \mathrm{H}-1$ and $\mathrm{H}-2$ ), 4.11-4.00 (minor isomer), 2.21 (br. $\mathrm{s}, 2 \mathrm{H}, \mathrm{OH}$ ),

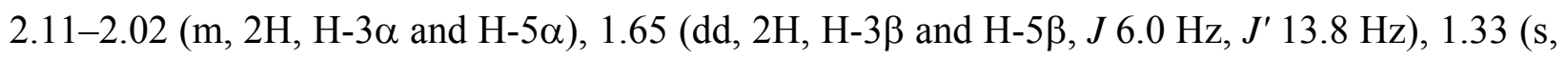
$3 \mathrm{H}, \mathrm{H}-4), 0.77\left(\mathrm{~s}, 9 \mathrm{H},\left(\mathrm{CH}_{3}\right)_{3} \mathrm{C}\right)$, and $0.00\left(\mathrm{~s}, 6 \mathrm{H},\left(\mathrm{CH}_{3}\right)_{2} \mathrm{Si}\right) ;{ }^{13} \mathrm{C}-\mathrm{NMR}\left(250 \mathrm{MHz}, \mathrm{CDCl}_{3}\right): \delta_{\mathrm{C}}$ 74.1, 72.6, 48.6, 29.6, 25.6, 17.8, and -2.5; $\operatorname{EIMS(CI)~m/z~(\% ):~} 247\left(16 \%, \mathrm{MH}^{+}\right) ; \mathrm{C}_{12} \mathrm{H}_{27} \mathrm{O}_{3} \mathrm{Si}$ requires 247.1729 , found 247.1718 .

3-Methyl-3-[tert-butyldimethylsilyloxy]pentane-1,5-dialdehyde (8). Sodium periodate (4.77 g, $22.28 \mathrm{mmol})$ was added to a solution of diol $7(5.48 \mathrm{~g}, 22.28 \mathrm{mmol})$ in dioxane and water $(1.08 \mathrm{~L}, 8: 2 \mathrm{v} / \mathrm{v})$ at room temperature. The reaction was stirred for $7 \mathrm{~h}$, and the inorganic solids were then removed by filtration. The filtrate was extracted with ethyl acetate $(3 \mathrm{x} 400 \mathrm{~mL})$. The combined organic layers were washed with brine $(2 \times 300 \mathrm{~mL})$, dried over $\mathrm{MgSO}_{4}$ and concentrated in vacuo. A mixture of dialdehyde 8 and hydrate 9 was obtained. This mixture was dissolved in dry THF and treated with ground $4 \AA$ molecular sieves $(21.5 \mathrm{~g})$. The resulting slurry was kept under $\mathrm{N}_{2}$ and heated with stirring to reflux for 2 hours. Then the reaction mixture was allowed to reach room temperature, filtered through a pad of Celite ${ }^{\circledR}$ and washed with $\mathrm{Et}_{2} \mathrm{O}$. Solvent was removed in vacuo to yield the pure dialdehyde 8 (5.13 g, 90\%), m.p. 80-82 ${ }^{\circ} \mathrm{C}$; IR (film) $v_{\max }: 2957,2930,1474$, and $1463 \mathrm{~cm}^{-1}$; ${ }^{1} \mathrm{H}-\mathrm{NMR}\left(400 \mathrm{MHz}, \mathrm{CDC1}_{3}\right): \delta_{\mathrm{H}} 9.70$ (t, $2 \mathrm{H}, \mathrm{H}-1$

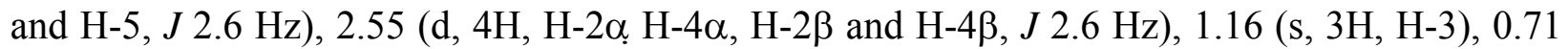
$\left(\mathrm{s}, 9 \mathrm{H},\left(\mathrm{CH}_{3}\right)_{3} \mathrm{C}\right)$, and $0.02\left(\mathrm{~s}, 6 \mathrm{H},\left(\mathrm{CH}_{3}\right)_{2} \mathrm{Si}\right) ;{ }^{13} \mathrm{C}-\mathrm{NMR}\left(250 \mathrm{MHz}, \mathrm{CDCl}_{3}\right): \delta_{\mathrm{C}} 201.2,67.1,55.5$, 
30.5, 25.7, 18.0, -2.2, and -3.6; EIMS(CI) m/z (\%): $245\left(50 \%, \mathrm{MH}^{+}\right)$, and $113\left(100 \%, \mathrm{M}^{+}-\right.$ OTBS); $\mathrm{C}_{12} \mathrm{H}_{25} \mathrm{O}_{3}$ Si requires 245.1573, found 245.1562.

2-Hydroxy-4-methyl-4-[tert-butyldimethylsilyloxy]tetrahydropyran (10). Sodium borohydride (0.06 g, $1.50 \mathrm{mmol}$ ) was added in two portions over $0.5 \mathrm{~h}$ to a solution of the dialdehyde $8(1 \mathrm{mmol})$ in dry methanol at $-30^{\circ} \mathrm{C}$. The reaction was stirred at $-30^{\circ} \mathrm{C}$ for $4 \mathrm{~h}$, and then warmed to room temperature. The reaction mixture was acidified with a $1 \mathrm{M}$ solution of $\mathrm{HCl}$ to $\mathrm{pH} 7.0$ and most of the $\mathrm{MeOH}$ and water was removed in vacuo. The residue was extracted with diethyl ether $(3 \times 50 \mathrm{~mL})$, washed with brine $(2 \times 50 \mathrm{~mL})$, dried over $\mathrm{MgSO}_{4}$ and concentrated in vacuo to give the crude lactol. Purification was attempted using column chromatography on silica gel, eluting with diethyl ether-light petroleum, $2: 3$. However, a pure sample of the lactol $\mathbf{1 0}$ was never obtained, and therefore the reaction mixtures were used crude for later steps. Colorless oil; IR (film) $v_{\max }: 3409,2956$, and $2930 \mathrm{~cm}^{-1}$; ${ }^{1} \mathrm{H}-\mathrm{NMR}$ (400

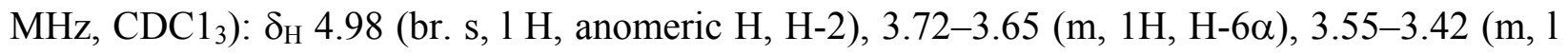

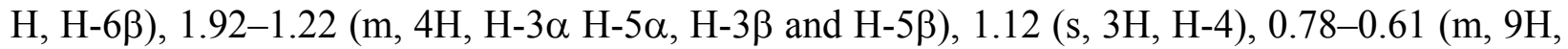
$\left.\left(\mathrm{CH}_{3}\right)_{3} \mathrm{C}\right)$, and 0.03-(-0.01) (m, 6H, $\left.\left(\mathrm{CH}_{3}\right)_{2} \mathrm{Si}\right) ; \operatorname{EIMS}(\mathrm{CI}) \mathrm{m} / \mathrm{z}(\%): 229\left(70 \%, \mathrm{M}^{+}-\mathrm{OH}\right)$; $\mathrm{C}_{12} \mathrm{H}_{25} \mathrm{O}_{2} \mathrm{Si}$ requires 229.1624, found 229.1618 .

2-Ethoxy-6-hydroxy-4-methyl-4-[tert-butyldimethylsilyoxy]tetrahydropyran (13). Ethanol (1 mmol) was added to a solution of the dialdehyde 8 (1 mmol) in dry THF $(5 \mathrm{~mL})$. The mixture was refluxed for $24 \mathrm{~h}$. The THF was then removed in vacuo to give crude lactol 13. Pale yellow oil; IR (film) $v_{\max }: 3421,2956$, and $2930 \mathrm{~cm}^{-1}$; ${ }^{1} \mathrm{H}-\mathrm{NMR}\left(250 \mathrm{MHz}, \mathrm{CDCl}_{3}\right): \delta_{\mathrm{H}} 5.23$ (br. s, $1 \mathrm{H}$, anomeric H-6 ), 5.10-5.03 (m, 1H, H-2), 3.94-3.87 (m, 1H, OC패CH 3$), 3.56-3.46(\mathrm{~m}, 1 \mathrm{H}$, $\left.\mathrm{OCH}^{-} \mathrm{HCH}_{3}\right), 1.92-1.36(\mathrm{~m}, 4 \mathrm{H}, \mathrm{H}-3 \alpha, \mathrm{H}-5 \alpha, \mathrm{H}-3 \beta$ and $\mathrm{H}-5 \beta), 1.29$ (s, 3H, H-4), 1.17 (t, 3H, $\left.\mathrm{OCH}_{2} \underline{\mathrm{CH}}_{3}\right), 0.84-0.78\left(\mathrm{~m}, 9 \mathrm{H},\left(\mathrm{CH}_{3}\right)_{3} \mathrm{C}\right)$, and 0.03-(-0.02) (m, 6H, $\left.\left(\mathrm{CH}_{3}\right)_{2} \mathrm{Si}\right) ; \mathrm{EIMS}(\mathrm{CI}) \mathrm{m} / \mathrm{z}$ (\%): $273\left(20 \%, \mathrm{M}^{+}-\mathrm{OH}\right), 245\left(25 \%, \mathrm{M}^{+}-\mathrm{OEt}\right)$, and $159\left(9 \%, \mathrm{M}^{+}-\mathrm{OTBS}\right) ; \mathrm{C}_{14} \mathrm{H}_{29} \mathrm{O}_{3}$ Si requires 273.1886 , found 273.1891 .

\section{General procedure for oxidation of lactols to lactones}

\section{5-Hydroxy-3-methyl-3-[tert-butyldimethylsilyloxy]pentanoic acid lactone 12, 5-Ethoxy-5-} hydroxy-3-methyl-3-[tert-butyldimethylsilyloxy]pentanoic acid lactone (14). A solution of the lactol $(1 \mathrm{mmol})$ in $\mathrm{CH}_{2} \mathrm{Cl}_{2}(20 \mathrm{~mL})$ was added to a suspension of pyridinium chlorochromate (0.32 g, $1.5 \mathrm{mmol})$ and ground $4 \AA$ molecular sieves $(400 \mathrm{mg})$ in $\mathrm{CH}_{2} \mathrm{Cl}_{2}(40 \mathrm{~mL})$ at room temperature. The reaction mixture was stirred vigorously at room temperature for $24 \mathrm{~h}$, diethyl ether $(50 \mathrm{~mL})$ was then added and the mixture was stirred for a further $1 \mathrm{~h}$. The suspension was filtered over a pad of silica gel, and washed through with further ether. The ether was removed in vacuo to give crude lactone. Compound 12: colorless oil (43\%, over 2 steps); IR (film) $v_{\max }$ : 2960, 2929, and $1743 \mathrm{~cm}^{-1}$; ${ }^{1} \mathrm{H}-\mathrm{NMR}\left(250 \mathrm{MHz}, \mathrm{CDCl}_{3}\right): \delta_{\mathrm{H}} 4.51-4.41(\mathrm{~m}, 1 \mathrm{H}, \mathrm{H}-5 \alpha), 4.26-$

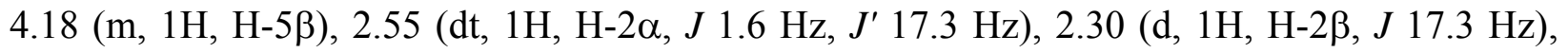
1.75-1.70 (m, 2H, H-4 $\alpha$ and $\mathrm{H}-4 \beta), 1.30(\mathrm{~s}, 3 \mathrm{H}, \mathrm{H}-3), 0.73\left(\mathrm{~s}, 9 \mathrm{H},\left(\mathrm{CH}_{3}\right)_{3} \mathrm{C}\right)$, and $-0.02(\mathrm{~d}, 6 \mathrm{H}$, $\left.\left(\mathrm{CH}_{3}\right)_{2} \mathrm{Si}, J 5.8 \mathrm{~Hz}\right) ;{ }^{13} \mathrm{C}-\mathrm{NMR}\left(250 \mathrm{MHz}, \mathrm{CDCl}_{3}\right): \delta_{\mathrm{C}} 172.5,73.0,68.6,47.8,39.3,31.5,28.0$, 20.3, 0.04, and 0.0; EIMS(CI) m/z (\%): $262\left(23 \%, \mathrm{M}+\mathrm{NH}_{4}{ }^{+}\right), 245\left(100 \%, \mathrm{M}+\mathrm{H}^{+}\right)$, and 113 (47\%, M-OTBS); $\mathrm{C}_{12} \mathrm{H}_{25} \mathrm{O}_{3} \mathrm{Si}$ requires 245.1573, found 245.1574. Compound 14: Colorless oil 
(0.14 g, $44 \%$ over two steps), (Found C, 58.2, H, 9.70\%; $\mathrm{C}_{14} \mathrm{H}_{28} \mathrm{O}_{4} \mathrm{Si}$ requires C, 58.3, H, 9.8\%); IR (film) $v_{\max }: 2932,2858$, and $1758 \mathrm{~cm}^{-1} ;{ }^{1} \mathrm{H}-\mathrm{NMR}\left(250 \mathrm{MHz}, \mathrm{CDCl}_{3}\right): \delta_{\mathrm{H}} 5.40(\mathrm{dd}, 1 \mathrm{H}, \mathrm{H}-5, J$ $4.2 \mathrm{~Hz}, J^{\prime} 8.1 \mathrm{~Hz}$ ), 4.03-3.90 (dq, 1H, $\mathrm{OCH} \mathrm{HCH}_{3}, J 2.5 \mathrm{~Hz}, J^{\prime} 7.1 \mathrm{~Hz}$ ), 3.62-3.50 (dq, 1H,

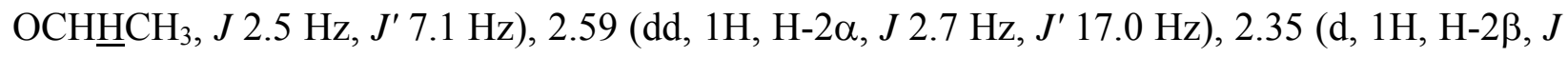

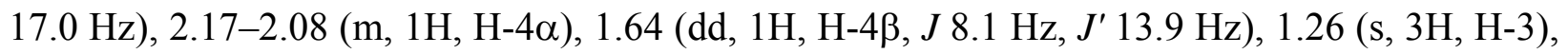
$1.13\left(\mathrm{t}, 3 \mathrm{H}, \mathrm{OCH}_{2} \mathrm{CH}_{3}, J 7.1 \mathrm{~Hz}\right), 0.74\left(\mathrm{~s}, 9 \mathrm{H},\left(\mathrm{CH}_{3}\right)_{3} \mathrm{C}\right)$, and $0.00\left(\mathrm{~s}, 6 \mathrm{H}\left(\mathrm{CH}_{3}\right)_{2} \mathrm{Si}\right) ;{ }^{13} \mathrm{C}-\mathrm{NMR}$ $\left(250 \mathrm{MHz}, \mathrm{CDCl}_{3}\right): \delta_{\mathrm{C}} 171.6,104.1,73.3,67.7,47.2,45.3,31.5,28.0,20.3,17.3,3.4$, and 0.1; EIMS(CI) m/z (\%): 289(5\%, $\left.\mathrm{MH}^{+}\right) ; \mathrm{C}_{14} \mathrm{H}_{29} \mathrm{O}_{4}$ Si requires 289.1835, found 289.1842.

Ethyl 3-methyl-5-oxo-3-[tert-butyldimethylsilyloxy]pentanoate (15). Sodium ethoxide $(1.4 \mathrm{~mL}, 0.1 \mathrm{M}$ solution, $0.14 \mathrm{mmol})$ was added dropwise to a solution of lactone $14(0.14 \mathrm{~g}$, $0.47 \mathrm{mmol})$ in diethyl ether $(7 \mathrm{~mL})$ at $0^{\circ} \mathrm{C}$. The reaction was stirred for $3 \mathrm{~h}$ at $0^{\circ} \mathrm{C}$, quenched with saturated $\mathrm{NH}_{4} \mathrm{Cl}(5 \mathrm{~mL})$, and then warmed to room temperature. The layers were separated and the aqueous layer was extracted with diethyl ether $(3 \times 30 \mathrm{~mL})$. The combined organic layers were washed with brine $(2 \times 30 \mathrm{~mL})$, dried over $\mathrm{MgSO}_{4}$ and concentrated in vacuo to give crude mono-ester. Purification by column chromatography on silica gel, eluting with diethyl etherlight petroleum 1:2 gave pure mono-aldehyde 15 as a colorless oil (0.04 g, $28 \%$ ) ; IR (film) $v_{\max }: 2932,2858,1730$, and $1728 \mathrm{~cm}^{-1} ;{ }^{1} \mathrm{H}-\mathrm{NMR}\left(250 \mathrm{MHz}, \mathrm{CDCl}_{3}\right): \delta_{\mathrm{H}} 9.75(\mathrm{t}, 1 \mathrm{H}, \mathrm{H}-5, J$

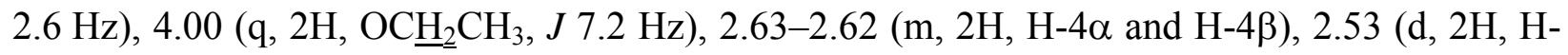
$2 \alpha$ and $\mathrm{H}-2 \beta, J 3.0 \mathrm{~Hz}), 1.36(\mathrm{~s}, 3 \mathrm{H}, \mathrm{H}-3), 1.14\left(\mathrm{t}, 3 \mathrm{H}, \mathrm{OCH}_{2} \mathrm{CH}_{3}, J 7.2 \mathrm{~Hz}\right), 0.72(\mathrm{~s}, 9 \mathrm{H}$, $\left.\left(\mathrm{CH}_{3}\right)_{3} \mathrm{C}\right)$, and $0.00\left(\mathrm{~d}, 6 \mathrm{H},\left(\mathrm{CH}_{3}\right)_{2} \mathrm{Si}, J 3.3 \mathrm{~Hz}\right) ;{ }^{13} \mathrm{C}-\mathrm{NMR}\left(250 \mathrm{MHz}, \mathrm{CDCl}_{3}\right): \delta_{\mathrm{C}} 204.1,172.4$, 75.3, 63.0, 56.8, 49.5, 30.9, 27.7, 20.1, 16.2, 0.00, and -0.01; $\operatorname{EIMS}(\mathrm{CI}) \mathrm{m} / \mathrm{z}(\%): 289$ (4\%, $\left.\mathrm{MH}^{+}\right)$, and $157\left(100 \%, \mathrm{M}^{+}\right.$-OTBS); $\mathrm{C}_{14} \mathrm{H}_{29} \mathrm{O}_{4}$ Si requires 289.1835, found 289.1824.

Racemic mevalonic acid lactone, $( \pm-2) . \mathrm{HCl}(3.5 \mathrm{~mL}, 10 \%)$ was added dropwise to a solution of protected lactone $12(0.03 \mathrm{~g}, 0.12 \mathrm{mmol})$ in THF $(1.5 \mathrm{~mL})$ at room temperature and was stirred at room temperature for $46 \mathrm{~h}$. The mixture was saturated with $\mathrm{NaCl}$, and extracted with hot ethyl acetate $(4 \times 10 \mathrm{~mL})$. The combined organic layers were washed with brine $(1 \times 2 \mathrm{~mL})$ and dried over $\mathrm{MgSO}_{4}$. Purification by column chromatography on silica gel, eluting with ethyl acetate gave pure racemic mevalonic acid lactone $( \pm)-2$ as a colorless oil $(0.004 \mathrm{~g}, 29 \%)$, IR (film) $v_{\max }: 3417,2967,2927$, and $1753 \mathrm{~cm}^{-1} ;{ }^{1} \mathrm{H}-\mathrm{NMR}\left(250 \mathrm{MHz}, \mathrm{CDCl}_{3}\right): \delta_{\mathrm{H}} 4.60-4.49(\mathrm{~m}$,

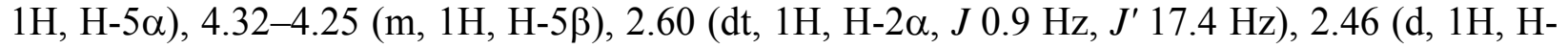
$2 \beta, J 17.4 \mathrm{~Hz}), 1.88-1.83(\mathrm{~m}, 2 \mathrm{H}, \mathrm{H} 4 \alpha$ and $\mathrm{H} 4 \beta)$, and $1.34(\mathrm{~s}, 3 \mathrm{H}, \mathrm{H}-3) ;{ }^{13} \mathrm{C}-\mathrm{NMR}(250 \mathrm{MHz}$, $\left.\mathrm{CDCl}_{3}\right): \delta_{\mathrm{C}} 169.9,67.2,65.0$, and 43.7, 34.8, 28.8; $\operatorname{EIMS}(\mathrm{CI}) \mathrm{m} / \mathrm{z}(\%): 148\left(9 \%, \mathrm{M}+\mathrm{NH}_{4}^{+}\right), 131$ $\left(100 \%, \mathrm{MH}^{+}\right)$, and $113\left(17 \%, \mathrm{M}^{+}-\mathrm{OH}\right) ; \mathrm{C}_{6} \mathrm{H}_{11} \mathrm{O}_{3}$ requires 131.0708, found 131.0701 .

\section{Acknowledgments}


S.L.J.B. thanks the University of Reading for a research studentship. A.J.M.-S. thanks the Secretaria de Estado de Universidades, Investigacion y desarrollo (SEUID; Spanish funding body) for a postdoctoral fellowship.

\section{References and Notes}

1. (a) Goldstein, J. L.; Brown, M. S. Nature 1990, 343, 425. (b) Casey, P. J. J. Lipid Res. 1992, 33, 1731. (c) Grünler, J.; Ericcson, J.; Dallner, G. Biochim. Biophys. Acta 1994, 1212, 259.

2. (a) Herbert, R. B. The Biosynthesis of Secondary Metabolites, $2^{\text {nd }}$ Edn; Chapman and Hall: London 1989. (b) Caspi, E. Tetrahedron 1986, 42, 3.

3. Folkers, K.; Shunk, C. H.; Linn, B. O.; Robinson, F. M.; Wittreich, P. E.; Huff, J. W.; Gilfillan, J. L.; Skeggs, H. R. Discovery and Elucidation of Mevalonic Acid in Ciba Foundation Symposium on the Biosynthesis of Terpenes and Sterols; Wolstenholme, G. E. W.; O’Connor, M., Eds; J. S. A. Churchill Ltd.: London, 1959; p 20.

4. (a) Fernandes, R. A.; Kumar, P. Tetrahedron: Asymmetry 1999 10, 4349. (b) Ray, N. C.; Raveendranath, P. C.; Spencer, T. A. Tetrahedron 1992, 48, 9427. (c) Bolitt, V.; Mioskowski, C.; Bhatt, R. K.; Falck, J. R. J. Org. Chem. 1991, 56, 4238. (d) Ohta, T.; Tabei, N.; Nozoe, S. Heterocycles 1989, 28, 425. (e) Schneider, J. A.; Yoshihara, K. J. Org. Chem. 1986, 51, 1077. (f) Mori, K.; Okada, K. Tetrahedron 1985, 41, 557. (g) Bonadies, F.; Rossi, G.; Bonini, C. Tetrahedron Lett. 1984, 25, 5431.

5. (a) Wilson, W. K.; Scallen, T. J.; Morrow, C. J. J. Lipid Res. 1982, 23, 645. (b) Cornforth, R. H.; Cornforth, J. W.; Popjak, G. Tetrahedron 1962, 18, 1351.

6. Eberle, M.; Arigoni, D. Helv. Chim. Acta 1960, 43, 1508.

7. Davis, F. A.; Reddy, G. V.; Chen, B. C.; Kumar, A.; Haque, M. S. J. Org. Chem. 1995, 60, 6148.

8. Shimizu, M.; Kamikubo, T.; Ogasawara, K. Tetrahedron: Asymmetry 1997, 8, 2519.

9. Kishida, M.; Yamauchi, N.; Sawada, K.; Ohashi, Y.; Eguchi, T.; Kakinuma, K. J. Chem. Soc., Perkin Trans. 1 1997, 891.

10. Abushanab, E.; Reed, D.; Suzuki, F.; Sih, C. J. Tetrahedron Lett. 1978, 3415.

11. (a) Frye, S. V.; Eliel, E. L. Tetrahedron Lett. 1986, 3223. (b) Frye, S. V.; Eliel, E. L. J. Am. Chem. Soc. 1988, 110, 484.

12. Kawakami, Y.; Hiratake, J.; Yamamoto, Y.; Oda, J. J. Chem. Soc., Chem. Commun. 1984, 779.

13. (a) Orru, R. V. A.; Osprian, I.; Kroutil, W.; Faber, K. Synthesis 1998, 1259. (b) Lakher, F. J.; Hager, L. P. J. Org. Chem. 1996, 61, 3923. (c) Ferraboschosi, P.; Grisenti, P.; Casati, S.; Santaniello, E. Synlett 1994, 754. (d) Sugai, T.; Kakeya, H.; Ohta, H. Tetrahedron 1990, 46, 3463. (e) Francis, C. J.; Jones, J. B. J. Chem. Soc., Chem. Commun. 1984, 579. (f) Ohta, H.; Tetsukawa, H.; Noto, N. J. Org. Chem. 1982, 47, 2400. (g) Irwin, A. J.; Jones, J. B. J. Am. 
Chem. Soc. 1977, 99, 556. (h) Huang, F. C.; Lee, L. F. H.; Mittal, R. S. D.; Ravikumar, P. R.; Chan, J. A.; Sih, C. J.; Caspi, E.; Eck, C. R. J. Am. Chem. Soc. 1975, 97, 4144.

14. (a) Willis, M. C. J. Chem. Soc., Perkin Trans. 1 1999, 1765. (b) Ward, R. S. Chem. Soc. Rev. 1990, 19, 1.

15. (a) Kann, N.; Rein, T. J. Org. Chem. 1993, 58, 3802. (b) Tullis, J. S.; Vares, L.; Kann, N.; Norrby, P-O. Rein, T. J. Org. Chem. 1998, 53, 8284. (c) Vares, L.; Rein, T. Org. Lett. 2000, 2, 2611. (d) BouzBouz, S.; Popkin, M. E.; Cossy, J. Org. Lett. 2000, 2, 3449. (e) Tanaka, K.; Ohta, Y.; Fuji, K. Tetrahedron Lett. 1993, 34, 4071. (e) Oppolzer, W.; De Brabander, J.; Walther, E.; Bernardinelli, G. Tetrahedron Lett. 1995, 36, 4413. (f) Oppolzer, W.; Walter, E.; Perez Balado, C.; De Brabander, J. Tetrahedron Lett. 1997, 38, 809. (g) Takemoto, Y.; Baba, Y.; Honda, A.; Nakao, S; Noguchi, I.; Iwata, C.; Tanaka, T.; Ibuka, T. Tetrahedron 1998, 54, 15567. (h) Takemoto, Y.; Baba, Y.; Noguchi, I.; Iwata, C. Tetrahedron Lett. 1996, 37, 3345. (i) Roush, W. R.; Park, J. C. Tetrahedron Lett. 1990, 31, 4707.

16. Buckley, S. L. J.; Drew, M. G. B.; Harwood'L. M.; Macías-Sánchez, A. J. Tetrahedron Lett. 2002, 43, 3593.

17. (a) Tullis, J. S.; Vares, L.; Kann, N.; Norrby, P-O. Rein, T. J. Org. Chem. 1998, 53, 8284.

(b) Harada, T.; Kagamihara, Y.; Tanaka, S.; Sakamoto, K.; Oku, A. J. Org. Chem. 1989, 54, 3816 .

18. Crandall, J. K.; Banks, D. B.; Colyer, R. A.; Watkins, R. J.; Arrington, J. P. J. Org. Chem. 1968, 33, 423.

19. Schammel, W. P.; Mertes, K. S. B.; Cristoph, G. G.; Busch, D. H. J. Am. Chem. Soc. 1974, $101,1623$.

20. Ray, R.; Matteson, D. S. Tetrahedron Lett. 1980, 21, 449.

21. Schniepp, L. E.; Geller, H. H. J. Am. Chem. Soc. 1946, 68, 1646.

22. Still, W. C.; Kahn, M.; Mitra, A. J. Org. Chem. 1978, 43, 2923.

23. Perrin, D.D.; Armarego, W.L.F. Purification of Laboratory Chemicals, $3^{\text {rd }}$ Edn, Pergamon Press: Oxford, 1988. 